\title{
Kamu Hizmetlerinin Sunumunda E-Belediyecilik Uygulamaları: Dört Farklı Büyükşehir Belediyesinin Karşılaştırmalı Analizi
}

\author{
E-Municipality Applications in Public Service Delivery: Comparative Analysis of Four Different \\ Metropolitan Municipalities
}

\author{
Hamza ATEŞ \\ Prof. Dr., Ístanbul Medeniyet Üniversitesi, SBF, \\ Siyaset Bilimi ve Kamu Yönetimi Bölümü, \\ hamza.ates@medeniyet.edu.tr \\ https://orcid.org/0000-0003-0975-0062
}

\section{A. Muhammet BANAZILI}

Arş. Gör., Doğuş Üniversitesi, İ̈BF,

Havacılık Yönetimi (Ingilizce) Bölümü,

mbanazili@dogus.edu.tr

https://orcid.org/0000-0002-5088-9587

\section{Anahtar \\ Kelimeler: \\ Kamu Hizmeti ve \\ E-Belediyecilik \\ Uygulamalarl, \\ Gaziantep BŞB,}

Kayseri $B S ̧ B$,

Kocaeli BŞB.,

Malatya BŞB.,

\section{Keywords:}

Public Services and

E-Municipality

Applications,

Gaziantep MM.,

Kayseri $M M$,

Kocaeli MM,

Malatya MM.

\section{ÖZET}

Vatandaşların yerel nitelikteki ihtiyaçlarının etkili, verimli ve sürekli olarak giderilmesinde mahalli idareler sürekli olarak kendisini değiştirmek ve dönüş̧ürmek durumundadır. Öyle ki içerisinde bulunduğumuz yüzyılın bilişim teknolojisi çağı olduğu göz önünde bulundurulduğunda devingen bir şekilde ilerleyen küresel çevreye bağlı olarak yerel yönetimler de etkilenmektedir. Yönetimdeki yeni eğilimlerin gerisinde kalınmaması ve halkın ihtiyaç duyduğu hizmetlerin kesintiye uğramaması açısından bir takım yöntemler kullanılmaktadır. Bu hizmet sunum yöntemlerinden biriside e-belediyecilik uygulamalarıdır. Zira E-devlet uygulamalarının önemli bir tamamlayıcısı olan e-belediye hizmetleri yerel yönetimlerde kendisine uygulama alanı bulmuştur. Çalışmanın amacl, yerel yönetimlerin kamu hizmeti sunma yöntemleri arasinda yer alan e-belediyecilik uygulamalarını ele almaktır. Bu kapsamda; Kocaeli, Malatya, Kayseri ve Gaziantep Büyükşehir Belediyelerinin belediyecilik uygulamaları, söz konusu belediyelerin web sayfaları üzerinden incelenmiştir. Elde edilen verilere-belediyecilik uygulamaları açısından karşılaştırmalı olarak analiz edilmiştir.

\section{ABSTRACT}

Local governments have to change and transform themselves continuously in order to meet the local needs of the citizens effectively, efficiently and continuously. In fact, considering that the present century is the era of information technology, it is affected by local governments depending on the dynamically moving global environment. A number of methods are used in order not to lag behind the novel trends in management and to prevent the interruption of the services that the public needs. One of the forms of service delivery is emunicipality applications. This is because e-municipality services, which are an important complement to egovernment applications, have found application in local governments. The aim of this study is to examine the e-municipality practices which are among the methods of providing local service to local governments. In this context; The municipal practices of Kocaeli, Malatya, Kayseri and Gaziantep Metropolitan Municipalities were examined through the websites of these municipalities. The obtained data were analyzed comparatively in terms of e-municipality applications. 


\section{GIRISs}

Değişen dünya şartlarına bağlı olarak kamu yönetimi yaklaşımları da değime eğilimi göstermektedir. Özellikle 1980’li yıllarda kamu yönetimin kapalı, çevresine karşı duyarsız ve hantal yapısı kamu yönetimindeki klasik yönetim anlayışlarının sorgulanmasına zemin hazırlamıştır (Önen, 2017:249). Küreselleşme olarak nitelendirilebilecek olan bu süreç ile birlikte kamu yönetimlerinde e-devlet modellerinin üretilmeye başlaması, bu sürecin en göze çarpan özelliklerinin başında yer almıştır (Maraş, 2011:122). Bu değişimler sosyal yaşantıyı siyasi, sosyal ve ekonomik açılardan etkilemesinin yanı sıra özellikle teknolojik gelişmelerin ivme kazanmasıyla kamuda bilgi iletişim teknolojilerinin yaygınlaşmasını da tetiklemiştir. Buna bağlı olarak e-devlet uygulamalarının önemli bir tamamlayıcısı olan e-belediye hizmetleri, yerel yönetimlerde kendisine uygulama alanı bulmuştur.

Günümüzde özellikle kamusal ihtiyaçlardaki çeşitliliğin artması, bürokrasinin ve kırtasiyeciliğin fazla olması ve hizmet sunumundaki etkinliğin sağlanabilmesi amacıyla yerel yönetimler yeni yöntem ve teknikler geliştirmektedir (Çukurçayır ve Eşki, 2001:90). Bunlardan birisi de, kamusal hizmetlerin elektronik ortama taşınması anlamına gelen e-belediyecilik uygulaması olmuştur. E-devlet projesinin ayrılmaz ve tamamlayıcı bir parçası olan e-belediyecilik uygulamaları ile vatandaşların ihtiyaç duydukları hizmetlerin çok yönlü olarak karşılanması amaçlanmaktadır.

E-devlet uygulamalarıyla devletler, teknolojiyle bütünleşmektedirler. Modern yapısal bir değişiklik olarak açıklanabilecek bu durum ile gerek hükümet ve yereldeki kuruluşlar arasındaki gerekse vatandaş ve işletmeler arasındaki ilişkiler ağının kurulması ve devlet ile işletmelerin her vatandaşa aynı kalite ve etkinlikte hizmet sunulmasının sağlanması hedeflenmiştir (Baştan ve Gökbunar, 2004:72).

E-belediyecilik uygulamalarıyla yalnızca hizmet sunumundaki nitelikler gelişmekle kalmamakta aynı zamanda yönetsel etkinliğin geliştirilmesine ve demokratik mekanizmaların teşvik edilmesine de imkân tanımaktadır (Gil-Garcia ve Pardo, 2005:201). Ayrıca, kamu idareleri içerisinde bilgi ve teknolojilerine yer verilmesi, ulusal düzeyde e-devlet; yerel düzeyde ise e-belediyecilik projelerini güçlendirerek kamu politikalarının oluşturulmasının ve demokratik süreçlerin iyileştirilmesinin de önünü açmaktadır (Layne ve Lee, 2001:124; Mecek, 2017:1826).

Bu kapsamda çalışmada ilk olarak kamu hizmeti ve e-belediyecilik kavramları açıklanmış ve Türkiye'deki uygulama alanları Kocaeli, Malatya, Kayseri ve Gaziantep Büyükşehir Belediyeleri özelinde karşılaştırmalı olarak analiz edilmiştir. Çalışmada söz konusu büyükşehir belediyelerine ait web sayfaları irdelenerek, kütüphane ve literatür taraması yapılmıştır. Elde edilen bulgular ilişkileri bakımından değerlendirilmiştir. Çalışmanın sonucunda, e-belediyecilik uygulamalarının işlerlik kazanabilmesi için gerekli olan belli başlı kriterleri söz konusu büyükşehir belediyelerinin genel itibariyle yerine getirdikleri saptanmıştır. Eksik veya yetersiz kaldıkları kriterde ise birtakım öneriler getirilmiştir..

\section{KAMU HİZMETINE İLIŞKİN KAVRAMSAL ÇERÇEVE}

Kamu malları ve hizmetleri insanların topluluk olarak bir arada yaşamaya başlamasından bu yana varlığını sürdürmektedir (Ökmen ve Çağatay, 2014:84). Kamu hizmetleri uzun bir geçmişi olan ve idare hukuku içerisinde en asli konuların başında yer almasının yanı sıra çokça tartışılan bir konu olmasıyla birlikte önemli bir olgu haline gelmiştir. Keza kamu hizmeti kavramı idare hukukçuları tarafindan üzerinde tam olarak ortak bir fikir birliğinin sağlanamadığı ihtilaflı bir alan olmuştur (Çal, 2007:601). Nitekim mahkeme kararlarında ve kanunlarda sürekli olarak kamu hizmeti kavramı geçse de bu kavramın kapsamı ve içeriği ile ilgili tartışmalar devam etmektedir. Kamu hizmeti kavramı sadece idare hukuku değil, tüm kamu hukuku içerisinde muğlak kalmış bir kavramdır (Derbil, 1950:28).

Kamu hizmeti kavramına ilişkin literatürde birçok tanım bulunduğundan dolayı kavramsal olarak kesin bir sınır oluşturmak mümkün değildir. İdare hukukunun en önemli öğreticilerinden olan Siddık Sami Onar (1966:12) kamu hizmetine; kamu yararıyla aynı anlam yükleyerek kamu hizmetinin idare hukukunun konusunu oluşturduğu ve hatta idare hukukunun kamu hizmeti kavramı üzerinde şekillendiğini belirtmiştir. En genel ifadeyle kamu hizmetlerini, yerel halkın ihtiyaç duyduğu ortak gereksinimlerin karşılanması amacıyla kamu aygıtı eliyle yerine getirilen hizmetler (Ateş ve Nohutçu, 2006:246) olarak tanımlamak mümkündür. Başka bir tanıma göre ise kamu hizmeti; devletin vatandaşların ihtiyaçlarını karşılamada "toplumsal çıkarı" gözettiği ve devletin sahip olduğu tüzel kişiliğin temsil edildiği bir olgudur (Matei ve Camelia, 2015:983). Özellikle yerel 
nitelikteki kamusal hizmetlerin giderilmesinde elinde teşebbüs gücü olmasından dolayı yerel yönetimler, başat aktörlerdendir (Eryllmaz, 2007:133). Yerel birimlerin kamu hizmetlerindeki etkinlik derecesi, yerel birimin büyüklüğü ile sunulan hizmetin büyüklüğü arasındaki ilişki bağlamında gelişmektedir (Atmaca, 2013:173).

Teknik olarak kamu hizmetinin farklı tanımları bulunmaktadır ve bu tanımlar başlıca üç çeşittir (Günday, 2011:330; Aky1lmaz vd., 2009:458);

1. Organik anlamda kamu hizmeti: Belli bir hizmeti yürütmek amacıyla kamu tüzel kişisi tarafindan görevlendirilmiş kamu görevlileri ve mali imkanları açıklamaktadır.

2. Maddi anlamda kamu hizmeti: Kamu yararına ve kamusal ihtiyaçlara dayalı faaliyetlerdir.

3. Şekil bakımından kamu hizmeti: Belli bir usulü ve belli rejimi ifade etmektedir.

Kamu hizmeti kavramının tanımsal çerçevesi her ne kadar dağınıklık gösterse de, bu hizmetlerin taşıması gereken belli başlı ilkeler ortaklık göstermektedir (Banazıl1, 2018:113). Bu ilkeler (Özay, 1986:42-44; Günday, 2011:334-336); "kesintisizlik (süreklilik) ve düzenlilik", "uyarlama (değişsenlik)", "nesnellik ve eşitlik", "meccanilik (değişmezlik)" ve "bedelsizlik" ilkeleridir. Belirtilen bu ilkelere kamu hizmetinin kamu yararını sekteye uğratmasını engellemek için uyulmaktadır. Kamu hizmetinin kapsamı, içeriği, özellikleri ve asli unsurları dikkate alındığında genel olarak (Mecek vd., 2015:483);

"Yasa koyucu ve/veya yasa koyucunun ihdas ettiği yetkiye dayanarak siyasi organlar tarafindan tatmininde kamu yararı veya çıkarının olduğu kabul edilen asli ve vazgeçilmez nitelikteki genel ve ortak bir gereksinimin (ihtiyacın) devlet, mahalli idareler ya da diğer kamu tüzel kişilerince ve/veya bir kamu tüzel kişisinin denetim ve gözetimi altında özel hukuk tüzel kişilerince ihtiyaç duyulduğu anlarda düzenli, sürekli ve istikrarlı bir şekilde topluma sunulmasına yönelik faaliyetlerdir",

şeklinde tanımlamak mümkündür. Bir takım hizmetlerin kamu hizmeti sayılabilmesi, ülkenin içinde bulunduğu koşullarla yakından ilişkisi bulunmaktadır. Bu açıdan kamu hizmeti, daha çok siyasi kararlarla belirlenir. Zaten yerel yönetimler ulusal düzeydeki siyasal süreçler ile ya tamamen bütünleşmiş olmakta ya da onlardan tamamen bağımsız bir görünüm sergilemektedirler (Keleş ve Yavuz, 1983:28). Genel olarak bakıldığında kamu hizmetleri; asayiş ve güvenlik, sağlı, temizlik, konut yapımı, eğitim, ulaşım, temiz su arzı, enerji temini ve televizyon yayıncılığı gibi faaliyetleri kapsamaktadır (Spicker, 2009:970; Ateş ve Banazıl1, 2019:71). Bunların yanı sıra belli başlı diğer kamu hizmetleri olarak; hastaların taşınması, araçların bakımı, mezarlık ve cenaze işleri, okul servisleri, eğlenme ve dinlenme mekânları, danışmanlık ve bilgi işlem hizmetleri ve binaların temizliği hizmetleri (Ersöz, 2001:37) sıralanabilir.

\section{E-BELEDIYYECILIIK KAVRAMI VE TÜRKIYYE'DEKİ UYGULAMA ALANLARI}

Devlet bir ülkedeki en gelişmiş ve en etkili örgüttür. Bu nedenle vatandaşlara sunduğu/sunacağ hizmetlerin niteliği de gelişmiş ve etkili olmalıdır (Çarıkçı, 2010:97). Bu doğrultuda vatandaşların istek ve beklentilerinin karşılanmasında en önemli rol yine vatandaşlara en yakın olan yerel yönetim organlarına düşmektedir. Özellikle bilgi teknolojilerinin her geçen gün kendisini ileri götürmesi ve küreselleşme rüzgârlarının yansıması olarak da hizmet çeşitliği artış göstermiş ve daha karmaşık bir hale almıştır (Tung ve Rieck, 2005:434; Sezer ve Vural, 2010:206). Nitekim e-devlet sistemi de, Türk Kamu Yönetimi'nde sunulan hizmetlerin yeniden inşa edilmesi tartışmalarında güncelliğini korumaktadır (Akcagündüz, 2013:127). Sonuç itibariyle değişen ve dönüşen çevre şartlarına ayak uydurmak kaçınılmaz bir gereklilik olmuş ve gerek merkezi yönetimler gerekse yerel yönetimler kendilerini reform etmişlerdir.

Vatandaşların ihtiyaçlarının sürekli olarak değişkenlik göstermesi ve her geçen gün yeni gereksinimlerin doğması ve bunların yerel yönetimler eliyle karşılanması hususunda ortaya koyulan fiziksel hizmetler bazen yetersiz kalabilmektedir. Özellikle kamu hizmetlerine hâkim olan; hizmette süreklilik ve etkililik ilkeleri gereğince yerel yönetimler vatandaşların ihtiyaçlarının sekteye uğramaması amacıyla e-belediyecilik uygulamalarını bünyelerine katmışlardır (Şahin, 2007:162). E-belediyecilik, hizmet sunumlarında vatandaşa kolaylık sağlamak amacıyla gerekli hizmetlerin, dijital ortamda vatandaşın hizmetine sunulmasıdır (Atmaca ve Y1lmaz, 2019:409).

E-Devletin sunmuş olduğu hizmetlerin bir parçasını oluşturan E-belediyecilik kavramına ilişkin literatürde birçok tanım olmasına rağmen en genel ifadeyle; vatandaşın ve devletin birbirlerine karşı olan görev ve hizmetlerin elektronik ortamda güvenli ve sürekli olarak yürütülmesi sürecidir (Y1lmaz, 2019:513; Atmaca, 
2009:34). E-belediyecilik kavramı, daha üst bir kavram olan e-devlet kavramı ile yakından ilişkilidir. E-devlet veya mobil-devlet; devlet faaliyetlerinde hem vatandaş hem de işletmeler açısından hizmetlerin sunulması amacıyla elektronik araç ve gereçlerden istifade edilmesi (Howard, 2001:6) şeklinde açıklanmaktadır. Erdal'a (2004:28) göre e-belediyecilik; hizmet sunumların katılımcılığı ve vatandaş odaklı olmayı ifade etmektedir. Ateş'e (2003:485) göre e-belediyecilik ise; geleneksel bürokratik işlemlerin elektronik ortama aktarılması olarak tanımlanmıştır. Önen vd.'ne (2018:1226) göre ise e-belediyecilik; şehir yaşamını daha yaşanabilir ve planlı kılan bunun yanında yönetimde açıklık, şeffaflık ve hesap verebilirlik gibi kritik öne sahip ilkeleri odak noktasına yerleştiren değişim süreci olarak ifade edilmiştir. Mecek (2017:1826-1827) e-devletten yola çıkarak geniş anlamda e-belediyecilik kavramını;

\begin{abstract}
"Kentsel kamu hizmetlerinin daha az bürokrasi ve kaynak kullanımı ile çok daha hızlı, kolay, ulaşllabilir, bütünsel, etkin, verimli, modern, eşit, şeffaf, denetlenebilir, hesap sorulabilir, doğrudan, güvenli, kaliteli ve kesintisiz bir şekilde yerine getirilebilmesi amactyla, belediyelerin birey ve kurumlarla açık ă̆ ortamında ya da sınırlı sayıda kullanıcı tarafindan erişim sağlanan kapalı ă̆ ortamlarında yazı, ses ve görüntü gibi sayısal verilerin işlenmesi, iletilmesi, saklanması, sorgulanmasl, değerlendirilmesi, denetlenmesi ve yönetilmesi temeline dayanan; bu kapsamda bilgi - iletissim teknolojilerinin kullanımiyla kullanicılarına dijital ortamda bilgi, hizmet ve mal allşverişinde bulunma; tanıtım, kamuoyu oluşturma, çift yönlü iletişim kurma, denetim, tercih, tasdik, tahsilat, başvuru, rezervasyon, belgelendirme, vd. online (gerçek zamanlı) işlem yapma imkanları sunan; bireysel katılımı ve demokrasi kültürünü artırıcı etkiye sahip, insan odakl hizmet sunumu anlayışıyla oluşturulmuş politika, model, süreç, sistem ve uygulamalar bütünüddür",
\end{abstract}

şeklinde tanımlamıştır. Öz olarak ya da detaylandırılarak yapılan tüm e-belediyecilik tanımlarından yola çıkarak e-belediyeciliğe ilişkin getirilen tanımların hem yönetsel açıdan, hem de siyasi açıdan değerlendirildiği anlaşılmaktadır. Bu durum e-belediyeciliğin çok boyutluluğunu ortaya koymaktadır.

E-belediye uygulamasıyla ulaşılmak istenen amaç, tüm vatandaşın yönetimde daha fazla yer almasını sağlamak, istenilen bilgiye ulaşılmayı kolaylaştırmak, zamandan tasarruf ederek vatandaşa daha nitelikli hizmetler sunarak tatmin derecesini artırmaktır (Şahin, 2007:167). Zira e-devletin önemli bir tamamlayıcısı olan e-belediyecilik, belediyelerin tüm açılardan ülke kalkınmasına olumlu katkı sağlayacak önemli bir projedir (Ünlü, 2018:78). Bu açıdan ele alındığında e-belediyecilik uygulamalarından, yönetim sürecini iyileştirmesi, hizmet sunumunu hızlandırması ve maliyetleri mümkün mertebede azaltması beklenmektedir. Ayrıca belediyelerin web hizmetlerini halka sunmasıyla, halkla olan ilişkilerde mesafe azalacak, yönetime katılma sağlanacak ve sosyal sorumluluk bilinci olgunlaşacaktır (Kaya Bensghir, 2001:80).

Kentler açısından e-belediyecilik uygulamaları iki açıdan önem taşımaktadır (Erdoğan, 2019:556). İlk olarak, imar, su, kanalizasyon, toplu taşıma, ulaşım ve insan kaynakları türündeki hizmetlerin giderilmesinde kolaylık sağlamaktır. İkinci olarak ise kamu hizmetlerinin sunumunda faydalanılan e-araçlar kent bürokrasisi ve vatandaş arasındaki iletişim kopukluğunu ortadan kaldırmak ve yerel demokrasiyi geliştirmektir.

Belirtilen kriterlerin yanı sıra e-belediyecilik uygulamasından beklenen diğer faydalar şu şekilde sıralanabilir (Şahin, 2007:168);

- Yerel kamu hizmetlerinin vatandaşın ihtiyaç duyduğu alanlara yönelik düzenlenmesi ve sunulması,

- Yerel kamu hizmetlerinin maliyetlerinin düşürülerek, bu hizmetlere zaman fark etmeksizin ulaşılabilmesi,

- Belediye sınırları içerisinde yaşayan tüm vatandaşın hizmete eşit uzaklıkta olması,

- Hesap verebilir ve şeffaf bir yerel yönetim yaklaşımının benimsenmesi,

- Yerel yönetim ile vatandaş arasındaki iletişimin güçlenmesi,

- Bürokratik işlemlerin azalmasıyla daha hızlı ve daha fazla hizmetin sunulabilmesi,

- Merkezi yönetim ve yerel yönetim arasındaki bilgi akışının sağlanması,

- Yerel sınırlar içerisinde yaşanan tüm gelişmelerin kolaylıkla takip edilebilmesidir.

E-belediyecilik kapsamında yukarıda sıralanan faydaların elde edilebilmesi için ise Siegfriede vd.'ne (2003:452454) göre belli başlı kriterlere bağlanmıştır. Bu kriterler şunlardır;

- E-belediyenin kabul görülerek içselleştirilmesi,

- Yerel halka ilişkin uyum çalışmaları amacıyla geniş yelpazeli modernizasyona gidilmesi, 
- E-belediyeciliğin temel yapı taşını oluşturan bilgi, iletişim, işlem ve katılımın bir arada entegre edilebilmesi,

- Fayda-Maliyet analizinin yapılması,

- Kamu-Özel ortaklıklarının desteklenmesi,

- E-belediyecilik projesinin sürdürülebilir ve uzun vadede halkın ihtiyaçlarını karşılayabilecek nitelikte olmas1,

- İhtiyaca göre doğru teknolojinin kullanılması,

- E-belediyecilik özel bir yasal bilgi gerekmektedir. Bundan dolayı yerel yönetimlerin bu alanla ilgili teknik bilgi birikimine sahip uzmanlara ulaşabilmesi için yeterli bütçeye sahip olmalıdır.

E-belediyeciliğe ilişkin yukarıda sıralanan temel unsurlar göz önünde bulundurulduğunda, e-belediyeciliğin yalnızca web sayfası açmak anlamına gelmediği ve yönetimsel olarak tüm süreçlerin bu platform vasıtasıyla hızlı, etkin ve verimli olarak tamamlanıp tamamlanmadığı esas önem arz eden noktadır (Henden ve Henden, 2005:56).

İdeal bir belediyecilik anlayışı için belediye organları sadece vatandaşla değil, gerek özel teşebbüslerle ve gerekse de uluslararası yerel yönetim birimleriyle iletişim içerisinde olmalıdır. Bu bakımdan yerel yönetimler çeşitli iletişim teknolojilerini uygulamaya koymaları gerekmektedir (Hazman, 2005:70). Ortaya konulacak olan uygulamalardaki nihai amaç; gönüllük ve katılım esaslı bir yerel yönetim zeminin oluşturulmasıyla birlikte etkili iletişimin kurulması ve nitelikli hizmet sunumunun sağlanmasıdır (Şat, 2008:212).

Küreselleşme hareketlerine bağlı olarak, Türkiye'de merkezi yönetime ait olan birtakım yetki ve sorumlulukların yerel yönetimlere devredilmesi gündeme gelmiştir. Bu doğrultuda, yerel yönetimlerin bilgi teknolojileriyle tanışmaları ve bunu kullanabilme kabiliyetlerinin geliştirilmesi gerekmekteydi (Ergun, 2004:140). Ortaya konulan tüm bu gelişmelere bağlı olarak, Türkiye'de e-belediyecilik çalışmaları özellikle 2001'den itibaren yaygınlık kazanmaya başlamıştır. $\mathrm{Bu}$ tarihten önce ise e-belediyecilik olarak nitelendirilebilecek bir uygulama 1989'da Türkiye Orta Doğu Amme İdaresi Enstitüsü (TODAİE)'ne bağlı olarak faaliyet yürüten "Yerel Yönetimler Araştırma ve Eğitim Merkezi” (YYAEM) kurulmuştur. Bu adımdan sonra belediye hizmet rehberinin yer aldığı ve ihale ilanlarının duyurulduğu "YERELNET" ağı oluşturulmuştur (Yıldız, 2007:43). Bunun yanı sıra 1998-2001 yılları arasında "Yerel Yönetimlerin Güçlendirilmesi Araştırması Projesi" (YERYÖN) ve 1999-2001 yılları arasında yerel yönetimlerde eğitim çalışmalarında bulunmak üzere "Yerel Yönetimler İçin Eğitim Malzemesi Geliştirme Projesi" (YEREP) oluşturulmuştur (Nohutçu ve Demirel, 2005:46). 2001 yılında ise mahalli idarelerin yerel halka hizmet sunumunda e-uygulamaların kullanılmasina yönelik "Yerel Bilgi Projesi" hayata geçirilmiştir.

2011 yılında Türkiye Belediyeler Birliği (TBB) tarafından belediyeler tarafından gerçekleştirilen mali ve idari işlemlerin denetlenebilmesi ve yerel halka daha hızlı ve nitelikli kamu hizmeti sunulabilmesi amacıyla "Belediye Bilgi Sistemi" (BELSİS) oluşturulmuştur. Yine İçişleri Bakanlığı tarafından tüm yerel yönetimler için tek tip bir e-belediye uygulaması geliştirilmek amacıyla "E-Belediye Bilgi Sistemi” kurulmuştur.

Son yıllarda Türkiye'deki yerel yönetimler kamu hizmetlerinin büyük bir kısmını e-belediye uygulamaları vasıtasıyla görmektedir. Yapılan bu uygulamalar genel itibariyle dört grup altında gerçekleştirilmektedir. Bunlar (Ulusoy ve Çobanoğulları, 2013:276);

i. Genel İşlemler: Üyelik ve nikah başvurusu, sicil işlemleri ve bina birim değerleri vb.

ii. Online Vezne İşlemleri: Borç ve tahsilat işlemlerinin kredi kartıyla ödeme imkânı sağlar.

iii. E-Beyanname İşlemleri: İlan, reklam, harç ve vergilerle ilgili ilan verme, ruhsat işlemleri,

iv. Online Başvurular: Belediyecilik faaliyetleri içerisindeki tüm istek, dilek ve şikayetlerin iletilmesini kapsamaktadır.

E-belediyecilik uygulamalarının vatandaşa sunmuş olduğu avantajlı getirilerinin olmasına karşılık bir takım sorunla da karşı karşıya kalındığını görülmektedir. E-belediyecilik uygulamaları sonucunda Türkiye'de karşılaşılan sorunlardan bazılarını şu şekilde belirtmek mümkündür (Pektaş, 2011:75):

- Kişisel verilerin muhafaza edilmesi açısından vatandaşın iletişim teknolojilerine karşı güvensizliği,

- İletişim teknolojilerine yapılan maliyetlerin yüksek olması, 
- Bilişim hukuku alanındaki çalışmaların parçalı ve yetersiz olması,

- Merkezi yönetim ve yerel yönetimler arasındaki iletişim eşgüdümünün yetersiz kalmas1,

- Kurum içi hizmet eğitimlerinin azlığı ve yöneticilerin yeniliklere karşı esnek olmaması,

- Belediyelerin çoğunda bilgi işlem servislerinin bulunmaması,

- Halkın katılımını teşvik edecek interaktif yöntemlerin uygulanmaması ve

- Bürokratik engellerin olmasıdır.

\section{DÖRT FARKLI BÜYÜKŞEHIR BELEDIYESINIIN E-BELEDIYYCILIKK UYGULAMALARININ ANALIZİ}

\subsection{Araștırmanın Yöntemi ve Evreni}

Araştırmada yazılı iletişimi sağlayan, içeriğin nesnel, açık, nicel tanımlamaları yapan ve sistematik bir araştırma yöntemi olan içerik analizi yöntemi kullanılmıştır (Berelson, 1971:18). Veriler yorumlanarak çıkarımlar formüle edilmeye çalış1lmıştır (Usta, 2012:152). Bu kapsamda araştırmanın evrenini Türkiye, örneklemini ise Kocaeli, Malatya, Kayseri ve Gaziantep Büyükşehir Belediyelerinin web adresleri teşkil etmektedir.

\section{2. Örneklem ve Verilerin Toplanması}

Örneklem olarak belirlenen büyükşehir belediyelerinin web siteleri incelenerek içerik analizine tabi tutulmuştur. Türkiye'de belediye web sayfaları incelenmiştir. Araştırmada elde edilen parametrelerden bir birine yakın olan ve/veya aynı olan kategoriler tercih edilmiştir. Bunun yanı sıra Kocaeli, Malatya, Kayseri ve Gaziantep Büyükşehir Belediyeleri'nin karşılaştırmalı olarak analiz edilmesinde Parlak vd. (2007:1195) tarafindan ebelediyecilik unsurları açısından kullanılmış olan "bilgi verme", "iletişim" ve "online işlemler" esas alınmıştır. Ayrica bu unsurlara, Alodalı vd. (2012:89) tarafından hazırlanan araştırmada yer alan belli başlı alt kriterler de eklenerek ele alınan dört büyükşehir belediyesinin e-belediyecilik faaliyetleri incelenmiştir. Söz konusu büyükşsehir belediyelerinin yerel hizmet sunumunda yararlandıkları e-belediyecilik uygulamalarını analiz edebilmek için web sayfaları taranmış ve elde edilen bulgular kodlama cetveline yerleştirilmiştir.

\subsection{Araştırmanın Bulguları ve Analizi}

Araştırmada seçilen büyükşehir belediyelerinin web adreslerine uygulanan içerik analizinin ardından ve belediyelerin yerel kamu hizmetlerinde sunmuş oldukları belli başlı hizmetleri incelenmiştir. Elde edilen bulgular tablolar halinde gösterilerek açıklanmıştır.

E-belediyecilik hizmetlerinin uygulanması ve çeşitlendirilmesi, büyükşehir statüsünde yer alan illerin nüfusları ve yüzölçümleri göz önünde bulundurulduğunda önemli bir enstrüman olduğu öne sürülebilir. Keza illerin sahip oldukları yüz ölçümlerinin miktarı ile hizmet sundukları alan arasında da paralel bir ilişki bulunmaktadır (Ateş ve Banazıl1, 2019:259). Öyle ki yüz ölçümü daha geniş olan bir ilin hizmet sunum alanıda genişeyecek ve karşılaması gereken ihtiyaçlarda çeşitlenecektir. $\mathrm{Bu}$ bağlamda araştırmaya konu edinilen büyükşehir belediyelerine ilişkin kimi genel bilgiler Tablo 1'de belirtilmiştir.

Tablo 1. Seçilen Büyükşehir Belediyelerine İlişkin Genel Bilgiler

\begin{tabular}{|c|c|c|c|c|}
\hline İller & Nüfusu (Toplam) & İlçe Sayısı & Yüz Ölçümü $\mathbf{( k m}^{2} \mathbf{)}$ & Belediye Web Adresi \\
\hline Kocaeli & 1.953 .035 & 12 & 3.626 & www.kocaeli.bel.tr/tr/ \\
\hline Malatya & 800.165 & 13 & 12.313 & www.malatya.bel.tr/ \\
\hline Kayseri & 1.407 .409 & 16 & 16.917 & www.kayseri.bel.tr/ \\
\hline Gaziantep & 2.069 .364 & 9 & 7.642 & www.gaziantep.bel.tr/tr \\
\hline
\end{tabular}

Kaynak: TÜİK Verilerinden Yararlanılarak Yazarlar Tarafından Hazırlanmıştır.

Örneklem olarak seçilen il belediyelerinin tamamı büyükşehir belediyesi statüsündedir. Kocaeli ili Marmara bölgesinde, Malatya ili Doğu Anadolu Bölgesinde, Kayseri ili İç Anadolu Bölgesinde ve Gaziantep ili de 
Güneydoğu Anadolu Bölgesinde yer almaktadır. İncelemeye esas belediyelerin matematiksel konumu ve demografik yapısı farklılıklar göstermektedir. Bunun temel nedeni; farklı konum ve kültürlerin e-belediyecilik hizmetlerine olan arz/talep farklılıklarını daha iyi tespit edebilmektir. Her dört büyükşehir belediyesi de aynı siyasi görüşe (Adalet ve Kalkınma Partisi) mensup belediye başkanları tarafından yönetilmektedir. Burada demografik farklılıkların yanında siyasal görüş farklılıklarının da eklenerek analizin zorlaşmasını engelleme amacı ön plana çıkmaktadır. Nüfus sayısı açısından en büyük kent Gaziantep iken, nüfus yoğunluğu açısından Kocaeli daha üst sırada yer almaktadır. Her iki kentte diğer iki kente göre daha çok nüfusu, ancak daha küçük toprak parçasına (yüzölçüme) sahiptirler. Bu durum kentler arasındaki demografik farklılıklara dayalı karşılaştırma yapılabilmesine katkı sağlamaktadır.

Tablo 2. Bilgi Verme Hizmetleri Açısından Analiz Edilmesi

\begin{tabular}{|c|c|c|c|c|c|}
\hline Belediyeler & $\begin{array}{c}\text { Kurumsal } \\
\text { Tanıtım }\end{array}$ & $\begin{array}{c}\text { Resmi } \\
\text { Başvurular } \\
\text { Için Belge } \\
\text { Temini }\end{array}$ & $\begin{array}{c}\text { Meclis } \\
\text { Kararlarının } \\
\text { Yayınlanması }\end{array}$ & $\begin{array}{c}\text { Stratejik } \\
\text { Planların ve } \\
\text { Faaliyet } \\
\text { Raporlarının } \\
\text { Yayınlanması }\end{array}$ & $\begin{array}{c}\text { Geçmiş ve } \\
\text { Gelecekte } \\
\text { Yapılacak } \\
\text { İhalelerin } \\
\text { Yayınlanması }\end{array}$ \\
\hline Kocaeli & + & + & + & + & + \\
\hline Malatya & + & + & + & + & + \\
\hline Kayseri & + & - & + & + & + \\
\hline Gaziantep & + & - & - & + \\
\hline
\end{tabular}

Araştırmaya konu olan dört büyükşehir belediyesinin e-belediyecilik uygulamaları "bilgi verme hizmetleri açısından" incelendiğinde, Kocaeli ve Malatya BŞB'nin beş farklı parametrenin tümünü uygulandığ 1 görülmektedir. Gaziantep BŞB'sinin ise bu hizmet türündeki faaliyetlerden ikisinde eksik olduğu anlaşılmaktadır. Belediyelerin yapacakları ihaleleri kamuoyuyla paylaşılmasında tüm büyükşehir belediyeleri resmi web sitelerinde paylaşırken, diğer belediyelerden ayrı olarak Kocaeli BŞB'nde ihale odası canlı yayın hizmeti de bulunmaktadır. Şüphesiz, ihale işlemlerinin, ilgili kişilerin gözlem ve bilgisine açık bir şekilde yapılması; kamunun, mahalli organlara karşı güvenini kazandıracaktır. Ayrıca belediyelerin kurumsal tanıtımlarını elektronik ortam vasıtasyla gerçekleştirmeleri hem belediyenin uluslararası mecrada tanınırlığını artırmada hem de belediyenin halkla olan ilişkilerinin güçlendirilmesinde önemli bir işlev görmektedir (Tanyıldızı ve Karatepe, 2011:521). Bu bağlamda bakıldığında söz konusu dört büyükşehir belediyesinin bu fonksiyonu yerine getirdikleri anlaşılmaktadır.

Tablo 3. İletişim Hizmetleri Açısından Analiz Edilmesi

\begin{tabular}{|c|c|c|c|c|c|}
\hline Belediyeler & $\begin{array}{c}\text { Beyaz Masa / } \\
\text { Çözüm Masası }\end{array}$ & $\begin{array}{c}\text { E-Bilgi } \\
\text { Edinme }\end{array}$ & $\begin{array}{c}\text { E-Talep ve E- } \\
\text { Şikâyet Formu }\end{array}$ & $\begin{array}{c}\text { Telefon } \\
\text { Belediyeciliği }\end{array}$ & Başkana Mesaj \\
\hline Kocaeli & + & + & - & + & + \\
\hline Malatya & + & + & + & + & + \\
\hline Kayseri & + & + & - & + & - \\
\hline Gaziantep & + & + & + & - & - \\
\hline
\end{tabular}

Dört BŞB'nin “iletişim hizmetleri” açısından sunmuş oldukları e-belediyecilik belediyeleri incelendiğinde beş parametrenin tümünü uygulayan tek belediyenin Malatya Büyükşehir Belediyesi’nin olduğunu fark edilmiştir. Kocaeli ve Kayseri BŞB'nin vatandaşların talep ve şikâyetlerini belediyeye ulaştırmasında e-talep/e-şikâyet olmayıp bu tür başvuruların yazılı olarak belediyedeki mercilere (beyaz masa veya çözüm masası) ulaştırıldığı saptanmıştır. Ayrıca belediye hizmetlerine ilişkin e-devlet üzerinden yapılan başvuruların sorgulanması, muhtarlık bilgi sistemi, kurs bilgi sistemi ve kazı ruhsatının takip edilmesi türündeki e-belediye hizmetlerinin Gaziantep BŞB'nde biraz daha az olduğu fark edilmiştir. Bu türdeki yazılı resmi belgelerin elektronik ortamda sunulamaması, bürokratik işlemlerin hacminin artmasına yol açarak, zaman kayıplarının yaşanmasına neden olacaktır. 
Tablo 4. Online Hizmet İşlem Hizmetleri Açısından Analiz Edilmesi

\begin{tabular}{|c|c|c|c|c|}
\hline Belediyeler & Fatura Ödeme & Vergi Ödeme & Anket & $\begin{array}{c}\text { Online Ruhsat ve } \\
\text { Lisans Verme }\end{array}$ \\
\hline Kocaeli & + & + & + & + \\
\hline Malatya & + & + & + & - \\
\hline Kayseri & + & + & + & - \\
\hline Gaziantep & + & + & + & + \\
\hline
\end{tabular}

Söz konusu BŞB'lerinin “online hizmet işlemleri” açısından sunmuş oldukları e-belediyecilik uygulamaları incelendiğinde ise, tüm BŞB'lerinin yukarıda analiz edilen e-hizmet türleri içerisinde en fazla yerine getirilen ebelediyecilik hizmeti olmuştur. Yalnızca online ruhsat ve lisans verme hizmetinde Malatya ve Kayseri BŞB'sinin geri kalması dikkat çekmektedir. Ayrıca dört BŞB'de hizmet memnuniyeti anketleri yaparak, elde ettikleri sonuçları faaliyet raporlarında yayınladıkları görülmüştür. Zira yerel yönetimler, vatandaşların memnuniyetlerini yüksek tutmak zorunda olan organlardır (Aslan ve Uluocak, 2012:176). Nitekim memnuniyet anketlerinin sıklıkla yapılması, kentlerde yaşayan insanların sorunlarının tespit edilerek, yaşam standartlarının yükseltilmesi için gerekli olan motivasyonları ortaya koyabilmesi açısından önem arz etmektedir.

\section{SONUÇ}

İçerisinde yaşadığımız dönemde yönetimler vatandaşların ihtiyaç duydukları hizmetleri gidermede genel itibariyle etkinlik, verimlilik, minimum düzeyde bürokrasi ve zamandan tasarruf etme türündeki önemli yönetim ilkeleriyle ortaya koymaktadır. Hizmetlerin sunumunda vatandaşa en yakın organlar olan yerel yönetimler, yerel hizmetleri elektronik ortama taşımaları durumunda gerek vatandaş gerekse personel açısından olumlu yansımaları olması muhtemeldir.

Araştırmada Kocaeli, Malatya, Kayseri ve Gaziantep B.Ş.B.'lerinin web sayfaları kapsamında e-belediyecilik hizmeti olarak sunmuş oldukları; "Bilgi Verme", İletişim” ve "Online Hizmet İşlemleri” kapsamında toplam üç ana faktör ve 14 alt faktör altında analiz edilmiştir. Bu doğrultuda şu bulgulara ulaşılmıştır; Seçilmiş olan 14 alt faktörün en fazla uygulandığı büyükşehir belediyeleri Kocaeli ve Malatya (13) olmuştur. Kayseri ve Gaziantep Büyükşehir Belediyeleri'nin ise 14 alt faktörden 10'unu uyguladıkları saptanmıştır.

Belediyelerin e-belediyecik uygulamaları ile ilgili eldeki skorları (yerine getirme düzeyleri) oldukça yüksektir. $\mathrm{Bu}$ durumun en temeli, ilgili belediyelerin büyükşehir statüsünde olmasıdır. Daha çok nüfus ve nüfus yoğunluğunun yaşanması, işlem hacimlerinin büyüklüğü, eğitim seviyesi yüksekliği, teknolojik alt yapının daha iyi standartta olması, mali ve insan kaynakları açısından diğer büyükşehir olmayan il belediyelerine göre daha iyi durumda olunması, vb. nedenler bu olumlu sonucun ortaya çıkmasına katkı sağlamaktadır. Statü olarak büyükşehirden il belediyesi ya da ilçe belediyesi statüsüne inildikçe yukarıda belirtilen birtakım imkân ve avantajlardan yoksun kalınılmakta ve başarı düzeyi de azalmaktadır. Ayrıca ülke genelindeki teknolojik alt yapı, nitelikli insan kaynakları, eğitim düzeyi, finansal imkânlar, e-belediyecilik hizmetlerine olan ihtiyaç düzeyi, vb. etmenlerin her geçen gün artması belediyelerin e-belediyecilik hizmetleri sunum düzeyini de yükseltmektedir. Yine 2020 yılı itibariyle tüm dünyada olumsuz etkisi görülen Covid-19 pandemi süreci de e-devlet, ebelediyecilik, vd. elektronik hizmetlerin yaygınlaşmasına ve etkinliğinin artmasına katkı sağladığı görülmektedir.

Akademik yazında daha önce yapılan bazı araştırma $^{1}$ sonuçları ile mevcut araştırmanın örneklemi (belediye türleri), yapılış tarihi ve elde edilen sonuçları kıyaslandığında yapılan değerlendirmenin tutarlılığı ve doğruluğu çok daha iyi anlaşılmaktadır. Örneğin yapılan araştırmaların yılları ilerledikçe ve örneklem alınan belediye türleri daha üst seviyelere çıkıldıkça e-belediye hizmetleri gerçekleştirme düzeylerinde artışlar görülmektedir.

Araştırmada örneklem olarak seçilen illerin skorları yüksek olmak ile birlikte esas alınan kriterleri/kıstasları \%100 oranında sağlamadıkları tespit edilmiştir. Başka bir ifadeyle belirtilen büyükşehir belediyelerinin genel itibariyle e-belediyecilik uygulamalarının çoğunluğunu yerine getirirken bir takım eksikliklerinin de olduğu anlaşılmaktadır. Bu eksiklikler şunlardır;

1 Örneğin; Yıldız (1999), Aktel (2009), Özüpek (2010), Genco (2010), Kabakuş (2014). Türkiye'de belediye web sayfaları ile ilgili akademik yazında yapılan içerik analizleri hakkında daha detaylı bilgi için Bkz.: Mecek (2017). 
- Özellikle Kocaeli ve Kayseri BŞB'lerinde e-talep ve e-şikâyet formlarının olmaması, vatandaşların belediyeye yönelik talep ve şikâyetlerinde cevap almalarında sürecin uzamasına, iki belediyenin iş yükünün artmasına ve personelin farklı işleri gerçekleştirmek için ayıracağı zamanın azalmasına neden olacaktır. Bu nedenle belediye web sayfalarına bu uygulamanın eklenmesi yararlı olacaktır.

- İkinci eksiklik, özellikle Gaziantep Büyükşehir Belediyesi’nin kent hakkında almış olduğu veya alacağı kararların vatandaşla paylaşılmasının önemli olduğu göz önünde bulundurulduğunda, meclis kararlarını elektronik ortamda yayınlanmamış olmasıdır.

- Üçüncü eksiklik ise, Kayseri ve Gaziantep BŞB'lerinde resmi başvurular için belge temin eksikliğinin olmasıdır. Şüphesiz bu durum belediyenin de iş ve eylemlerinin hızlı işlemesini sekteye uğratacak ve toplumsal fayda önünde engel olacaktır.

Genel itibariyle bakıldığında e-devlet anlayışının yansıması olan e-belediyecilik uygulamalarının sunmuş olduğu belli başlı kriterlerin araştırmaya konu edinen büyükşehir belediyeleri tarafindan büyük ölçüde yerine getirildiği anlaşılmıştır. $\mathrm{Bu}$ durum başta belediyelerde ş̧effaflığın sağlanması ve demokratik katılımın sağlanması açısından önemli bir gelişmedir. E-belediyecilik alanındaki hizmetlerin çeşitlendirilmesi ve mevcut olan eksikliklerin giderilmesi kamu bürokrasisini azaltmasının yanı sıra vatandaşın hizmete karşı tatmin düzeyini de artıracağı öne sürülebilir.

\section{KAYNAKÇA}

AKCAGÜNDÜZ, Emre (2013), “Türkiye'de E-Devlet Sistemine Farklı Bir Bakış: E-Devlet ve Tasarruf İlişkisi”, Doğuş Üniversitesi Dergisi, S.12(2), ss.127-140.

AKTEL, Mehmet (2009), "İl Belediye Web Sitelerinin İşlevselliği Üzerine Bir Araştırma", Süleyman Demirel Üniversitesi İïF Dergisi, S.14(2), ss.223-240.

AKYILMAZ, Bahtiyar, SEZGİNER, Murat ve KAYA, Cemil (2009), Türk İdare Hukuku, Seçkin Yayınevi, Ankara.

ALODALI, Fatih Bilal, TUNCER, Aziz, USTA, Sefa ve HALİS, Mine (2012), "Yerel Yönetimlerde EBelediyecilik Uygulamalarl: Akdeniz Bölgesi Örneğì", Manas Sosyal Araştırmalar Dergisi, S.1(1), ss.84-95.

ASLAN, Cumhur ve ULUOCAK, Şeref (2012), “Belediye Hizmetlerinden Memnuniyet Düzeyleri Üzerine Bir Araştırma: Çanakkale Örneği”, Uluslararası İnsan Bilimleri Dergisi, S.9(1), ss.175-200.

ATEŞ, Hamza (2003), “E-Devlet’in Kurumsal Temelleri: Eleştirel Bir Yaklaşım”, Kamu Yönetiminde Kalite 3. Ulusal Kongresi Bildiriler Kitabı, TODAİE Yayını, Ankara, ss.481-500.

ATEŞ, Hamza ve BANAZILI, A. Muhammet (2019), "Kamu Hizmetlerinin Sunumunda Yeni Bir Uygulama Yöntemi: Yeniden Belediyeleştirme (Re-Municipalisation) Modeli", Uluslararası Kamu Yönetimi Formu (KAYFOR17) Bildiriler Kitabı, 24-26 Ekim 2019, Karaman, ss.69-78.

ATEŞ, Hamza ve BANAZILI, A. Muhammet (2019), "Yerel Yönetimlerin İnsan Kaynakları İstihdam Biçimleri ve Demografik Özellikleri Açısından İncelenmesi: İstanbul Kadıköy ve Maltepe İlçe Belediyeleri Örneği”, 1. Uluslararası İletişim ve Yönetim Bilimleri Kongresi Bildiriler Kitabı, 26-28 Eylül 2019, Malatya, ss.249-263.

ATEŞ, Hamza ve NOHUTÇU, Ahmet (2006), “Kamu Hizmeti Sunumunda Gönüllü Kuruluşlar ve Devlet”, S.Ü. IïBF Sosyal ve Ekonomik Araştırmalar Dergisi, S.6(11), ss.245-276.

ATMACA, Kemal (2009), “E-Devlet'ten Olgun Devlet'e ya da E-Devlet'in Olgunlaştırllması”, Denetişim Dergisi, S.2, ss.31-43.

ATMACA, Yıldız (2013), "Optimal Belediye Büyüklüğü ve Yeni Büyükşehir Belediye Yasası", Çankırı Karatekin Üniversitesi İktisadi ve İdari Bilimler Fakültesi Dergisi, S.3(2), ss.168-185.

ATMACA, Yıldız ve YILMAZ, Vedat (2019), "Digitalised Local Management and Participatory Municipalism: Çankiri Municipality Case", Theory and Practice in Social Sciences (Ed. Viliyan KRYSTEV, Recep EFE, Emin ATASOY), St. Kliment Ohridski University Press, Sofia, ss.403-417. 
BANAZILI, Abdurrahman Muhammet (2018), "Yerel Kamu Hizmeti Sunumunda 'Yeniden Belediyeleştirme (Remunicipalisation)': OECD Ülkeleri ve Türkiye'den Uygulama Örnekleri”, Medeniyet Araştırmaları Dergisi, S.3(6), ss.111-132.

BAŞTAN, Serhat ve GÖKBUNAR, Ramazan (2004), "Kamu Hizmetlerinin Sunumunda E-Devletle Ilgili Yeni Gelişmeler: Tümleşik E-Devlet Sistemlerine Doğru”, Dokuz Eylül Üniversitesi İïF Dergisi, S.19(1), ss.71-89.

BERELSON, Bernard (1971), Content Analysis in Communication Research, Hafner Publishing, New York.

ÇAL, Sedat (2007), “Kamu Hizmeti: Bir Tanım Denemesi”, Gazi Üniversitesi Hukuk Fakültesi Dergisi, S.6(1-2), ss.599-655.

ÇARIKÇI, Oğuzhan (2010), “Türkiye'de E-devlet Uygulamaları Üzerine Bir Araştırma”, SDÜ Sosyal Bilimler Enstitüsü Dergisi, S.12, ss.95-122.

ÇUKURÇAYIR, M. Akif ve EŞKİ, Hülya (2001), “Kamu Hizmeti Sunumunda Yeni Yöntemler”, S.Ü. İİBF Sosyal ve Ekonomik Araştırmalar Dergisi, S.1(1/2), ss.89-109.

DERBİL, Süheyp (1950), “Kamu Hizmeti Nedir?”, Ankara Üniversitesi Hukuk Fakültesi Mecmuası, S.7(3/34), ss.28-36.

ERDAL, Murat (2004), Elektronik Devlet: E-Türkiye ve Kurumsal Dönüşüm, Filiz Kitabevi, İstanbul.

ERDOĞAN, Oğuzhan (2019), "Yerel Yönetimlerde E-Belediye Uygulamaları: İçişleri Bakanlı̆̆ E-Belediye Bilgi Sistemi”, Süleyman Demirel Üniversitesi İïBF Dergisi, S.24(3), ss.551-566.

ERGUN, Turgay (2004), Kamu Yönetimi Kuram ve Siyasa Oluşturma, TODAİE Yayınları, Ankara.

ERSÖZ, Halis Yunus (2001), "Yerel Yönetimlerde Özelleştirme Uygulamaları ve Yaygınlık Derecesi”, Çağdaş Yerel Yönetimler Dergisi, S.10(2), ss.31-50.

ERYILMAZ, Bilal (2007), Kamu Yönetimi, Erkam Matbaası, İstanbul.

GENCO, Mehmet İlker (2010), “Türkiye'de Yerel Yönetimlerde E-Belediyecilik Uygulamaları ve Gelişim Süreci”, Yüksek Lisans Tezi, Mustafa Kemal Üniversitesi Sosyal Bilimler Enstitüsü, Hatay.

GIL-GARCIA, J. Ramon ve PARDO, A. Theresa (2005), "E-Government Success Factors: Mapping Practical Tools to Theoretical Foundations", Government Information Quarterly, S.22(2), ss.187-216.

GÜNDAY, Metin (2011), İdare Hukuku, İmaj Yayınevi, Ankara, 10. Bask1.

HAZMAN, Gülsüm Gürler (2005), "Afyonkarahisar Belediyesi E-Belediye Uygulamalarl ve Yerel Farkındalı", Afyon Kocatepe Üniversitesi İïBF Dergisi, S.7(2), ss.65-84.

HENDEN, Burçin ve HENDEN, Rıfkı (2005), "Yerel Yönetimlerin Hizmet Sunumlarındaki Değişim ve EBelediyecilik”, Elektronik Sosyal Bilimler Dergisi, S.4(14), ss.48-66.

HOWARD, Mark (2001), "E-Government Across the Globe: How Will "e" Change Government?". Government Finance Review, S.(Ağustos), ss.3-9.

KABAKUŞ, Ahmet Kamil (2014), "Türkiye'deki Büyükssehirlerin Illçe Belediyelerine Göre E-Belediye Hizmetlerinde Etkinliğinin Veri Zarflama Analizi ile Ölçülmesi", Atatürk Üniversitesi Sosyal Bilimler Enstitüsü Dergisi, S.18(3), ss.307-324.

KAYA BENSGHIR, Türksel (2001), “Web'deki Belediyelerimiz: Konya Büyükşehir Belediyesi”, Çağdaş Yerel Yönetimler Dergisi, S.10(4), ss.80-95.

KELEŞ, Ruşen ve YAVUZ, Fehmi (1983), Yerel Yönetimler, Turhan Kitabevi, Ankara.

LAYNE, Karen ve LEE, Jungwoo (2001), "Developing Fully Functional E-government: A Four Stage Mode”, Government Information Quarterly, S.18, ss.122-136.

MARAŞ, Gökçe (2011), “Катu Yönetimlerinde E-Devlet ve E-Demokrasi İlişkisi”, Erciyes Üniversitesi İktisadi ve İdari Bilimler Fakültesi Dergisi, S.37, ss.121-144.

MATEI, Ani ve CAMELIA, Gaita (2015), "Public Service in Romania and its Role in the Development of the Administrative Capacity", Procedia Economics and Finance, S.23, ss.982-985. 
MECEK, Gülsevil, DOĞAN, Mesut ve KAYMAZ, Ali Rıza (2015), "Yerel Yönetim Hizmetlerinin Finansmaninda ve Sunumunda Alternatif Bir Model: KÖSİ (Kamu - Özel Sektör İşbirliği) Uygulamaları", İdari ve Mali Açıdan Türkiye'de Yerel Yönetimler (Ed. Mehmet MECEK, Mesut DOĞAN, Bekir PARLAK), Bekad Yayınları, Antalya, ss.481-506.

MECEK, Mehmet (2017), "E-Devlet ve E-Belediye: Kavramsal Çerçeve ve Türkiye'de Belediye Web Sitelerine Yönelik Yapılan Çalışmaların Değerlendirilmesi”, Süleyman Demirel Üniversitesi İktisadi ve İdari Bilimler Fakültesi Dergisi, S.22(KAYFOR15 Özel Say1s1), ss.1815-1851.

NOHUTÇU, Ahmet ve DEMİREL, Demokaan (2005), "Türkiye'de E-Devlet Uygulamaları", Türk İdare Dergisi, S.477, ss.35-56.

ONAR, Sıddık Sami (1966), İdare Hukukunun Umumi Esasları, Hak Kitabevi, İstanbul.

ÖKMEN, Mustafa ve ÇAĞATAY, Uluç (2014), "Kamu Hizmeti-Yerel Hizmet İlişkisi ve Açılımları Üzerine Notlar", Yerel Politikalar Dergisi, S.6, ss.77-104.

ÖNEN, Semih Mustafa (2017), "Kamu Yönetiminin Değişiminde Açıklık Anlayışı: Malatya Büyükşehir Belediyesi’nin Yeni Belediyecilik Uygulamaları”, Üçüncü Sektör Sosyal Ekonomi Dergisi, S.52(2), ss.248-265.

ÖNEN, Semih Mustafa, KARATEPE, Selma ve OZAN, Mehmet Seyda (2018), "E-Belediyecilik Çalışmaları Kapsamında Web Sitesi Uygulamaları: İki Farklı Ülke Belediyesi Üzerinden Bir Karşılaştırma”, Kent Yönetiminde Yeni Yaklaşımlar ve Etkin Belediyecilik Uygulamaları (Ed. Mehmet MECEK, Bekir PARLAK, Emin ATASOY), Nobel Yayınc1lik, Ankara, ss.1225-1236.

ÖZAY, İlhan (1986), Devlet İdari Rejim ve Yargısal Korunma, Filiz Kitabevi, İstanbul.

ÖZÜPEK, M. Nejat (2010), "Belediyelerin Halkla İlişkiler Çalışmalarında İnternet Kullanımı: Büyükşehir Belediyeleri Web Siteleri Üzerine Uygulamalı Bir Çalışma", Selçuk İletişim Dergisi, S.6(3), ss.196-205.

PARLAK, Bekir, SOBACI, Zahid ve CANTÜRK, Caner (2007), "Marmara Bölgesindeki Büyükşehir Belediyelerinin Website Temelli E-Devlet Hizmetleri: Karşılaştırmalı Bir İşlevsellik Analizi”, VI. Bilgi Ekonomi ve Yönetim Kongresi Bildiriler Kitabı, C.2, İstanbul, ss.1192-1203.

PEKTAŞ, Kadri Ethem (2011), "Belediye Hizmetlerinde Bilgi-İletişim Teknolojilerinin Kullanımı ve E-Belediye Uygulamalarındaki Son Gelişmeler: Bir Literatür Taraması”, Sosyal Bilimler Dergisi, S.8(1), ss.65-88.

SEZER, Özcan ve VURAL, Tarık (2010), "Kamu Hizmetlerinin Sunumunda Devletin Değişsen Rolü ve Merkezi Yönetim ile Yerel Yönetimler Arasında Yetki ve Görev Paylaşımı”, Maliye Dergisi, S.15, ss.203-219.

SIEGFRIEDE, Tina, GRABOW, Bussa ve DRUKE, Helmut (2003), "Ten Factors for Succes for Local Community E-Government", Electronic Government (Ed. R. Traunmüller), German Institute, Berlin, ss.452-455.

SPICKER, Paul (2009), "The Nature of Public Service", International Journal of Public Administration, S.32(11), ss.970-991.

ŞAHIN, Ali (2007), "Türkiye'de E-Belediye Uygulamaları ve Konya Örneği", Erciyes Üniversitesi İiBF Dergisi, S.29, ss.161-189.

ŞAT, Nur (2008), "Demokrasi İçin Bir Araç: E-Belediye”, Yayımlanmamış Doktora Tezi, Marmara Üniversitesi Sosyal Bilimler Enstitüsü, İstanbul.

TANYILDIZI, Nural İmik ve KARATEPE, Selma (2011), "Belediyelerin Halkla İlişkiler Çalışmalarında Web Siteleri: İki Farklı Ülke ve İki Farklı Belediye Analizi”, e-Journal of New World Sciences Academy, S.6(3), ss.520-538.

TUNG, Lai- Lai ve RIECK, Olaf (2005), "Adoption of Electronic Government Services Among Business Organizations In Singapure", The Journal of Strategic Information Systems, S.14(4), ss.417-440.

ULUSOY, Ahmet ve ÇOBANOĞULLARI, Gökhan (2013), "Trabzon Belediyesi Örneğinde E-Belediyecilik Uygulamaları", Türk İdare Dergisi, S.477, ss.269-284.

USTA, Aydın (2012), "Sorunsaldan Sonuçlara Bilimsel Araştırma Süreci: Bir Araştırma Raporu Modeli Örneği”, ODTÜ Sosyal Bilimler Enstitüsü Sosyal Bilimler Araştırmaları Dergisi, S.3(5), ss.135-161. 
ÜNLÜ, Ufuk (2016), "Sosyal Belediyecilik Anlayışının E-Belediyecilik Uygulamalarına Entegre Edilmesi”, Sayıştay Dergisi, S.102, ss.63-89.

YILDIZ, Mete (1999), "Yerel Yönetimlerde Yeni Bir Katıllm Kanall, Internet: Türkiye ve ABD'de Elektronik Kamu Bilgi Ağları", Çağdaş Yerel Yönetimler Dergisi, S.8(4), ss.144-156.

YILDIZ, Mete (2007), “Uluslararası Kuruluşların Türkiye'nin E-Devlet Siyasalarına Etkisi”, Amme İdaresi Dergisi, S.40(2), ss.39-55.

YILMAZ, Vedat (2019), "Doğu Anadolu Bölgesinde E-Belediyecilik Hizmetlerinin Yerel Halk Tarafindan Kullanım Düzeylerinin Değerlendirilmesi: Bitlis ve Muş Belediyesi Örnekleri”, E-Yönetişim (Ed. Bekir Parlak ve Kadir Caner Doğan), Beta Yayınları, İstanbul, ss.509-532.

http://malatya.bel.tr/ (Erişim Tarihi: 08.05.2020).

https://gaziantep.bel.tr/index.html (Erişim Tarihi: 08.05.2020).

https://www.kayseri.bel.tr/ (Erişim Tarihi: 07.06.2020).

https://www.kocaeli.bel.tr/ (Erişim Tarihi: 07.06.2020). 